\title{
Hepatitis B virus vaccination status of sixth year medical students
}

\author{
Oana Streinu-Cercel ${ }^{1,2^{*}}$, Anca Streinu-Cercel ${ }^{1,2}$, Liliana Lucia Preoțescu ${ }^{1,2}$, Adrian Streinu-Cercel ${ }^{1,2}$ \\ From The 9th Edition of the Scientific Days of the National Institute for Infectious Diseases Prof Dr Matei Bals \\ Bucharest, Romania. 23-25 October 2013
}

\section{Background}

Hepatitis B virus (HBV) infection can associate a high risk of progression to chronic hepatitis, particularly when infection occurs at younger ages. For this particular reason, newborn vaccination has been introduced in national immunization schedules in countries where the infection has a medium to high prevalence.

We assessed the vaccination status of students in their final year of medical university training during 20112013. This category is at risk of professional exposure to HBV and given the timeline of introduction of HBV vaccination in Romania, they probably have not been vaccinated at birth, but rather during middle or high school education.

\section{Methods}

We informed all medical students attending the Infectious Diseases rotation in their $6^{\text {th }}$ year of medical school regarding the possibility of determining their HBV serological status and filling out a standardized questionnaire. We correlated this information with the results of lab tests. We analyzed data with SPSS Statistics 20 (IBM).

\section{Results}

A total of 59 students (of which 17 were males) filled out the questionnaire. The mean age was $25 \pm 3$ years. Of these students, 40 were aware of their vaccination status for HBV but only 10 were able to mention the exact date of the first vaccination and 13 were able to mention their last booster shot. In the group of 47 students that had recent lab results, all had negative HBs antigen, and the median HBs antibody $(\mathrm{Ab})$ lab result was: $134 \pm 497$. Of them, 11 were considered as unprotected $(\mathrm{HBsAb} \leq 10)$,

\footnotetext{
* Correspondence: oanastreinucercel@gmail.com

${ }^{1}$ Carol Davila University of Medicine and Pharmacy, Bucharest, Romania
}

Full list of author information is available at the end of the article
12 had values between 10-100, 15 between 100-1000 and 9 above 1000 .

\section{Conclusion}

Most of the students that participated in this study were aware of their vaccination status for HBV, however, many of them were considered as unprotected, based on $\mathrm{HBsAb}$ results. Cellular immunity is also known to play an important role in protection from HBV infection; however, at this point no instruments are available to quantify specific memory cells in current clinical practice.

\section{Authors' details \\ ${ }^{1}$ Carol Davila University of Medicine and Pharmacy, Bucharest, Romania. ${ }^{2}$ National Institute for Infectious Diseases "Prof. Dr. Matei Balş", Bucharest, Romania.}

Published: 16 December 2013

doi:10.1186/1471-2334-13-S1-P29

Cite this article as: Streinu-Cercel et al:: Hepatitis B virus vaccination status of sixth year medical students. BMC Infectious Diseases 2013 13(Suppl 1):P29.

Submit your next manuscript to BioMed Central and take full advantage of:

- Convenient online submission

- Thorough peer review

- No space constraints or color figure charges

- Immediate publication on acceptance

- Inclusion in PubMed, CAS, Scopus and Google Scholar

- Research which is freely available for redistribution

\section{Ciomed Central}

